\title{
MED POSLOM IN DOMOLJUBJEM: ETNIČNA EKONOMIJA IN SLOVENCI ZUNAJ REPUBLIKE SLOVENIJE
}

\author{
Zvone ŽIGON
}

COBISS 1.02

\section{IZVLEČEK}

Med poslom in domoljubjem: Etnična ekonomija in Slovenci zunaj Republike Slovenije Avtor v članku najprej opiše različne pojavne oblike in značilnosti etničnih ekonomij, nato pa se osredotoči na slovenske skupnosti v zamejstvu in po svetu. Ugotavlja, da so posamezne etnične ekonomije odvisne od socialne in izobrazbene strukture pripadnikov etničnih skupnosti in od zgodovinskega in političnogeografskega konteksta njihovega nastanka. Na podlagi izkušenj sklene, da slovensko ekonomijo in politiko čakajo še številni koraki v smeri spodbujanja razvoja in »implementacije« slovenskega modela etnične ekonomije. Opaža spremembe pojma »slovenski izseljenec«, saj ta danes pomeni nekaj drugega kot v preteklosti, to so namreč lahko študent, ki v tujini pridobiva izkušnje, strokovnjak ali pogumni podjetnik.

KLJUČNE BESEDE: slovensko izseljenstvo, etnična ekonomija, etnična identiteta

\section{ABSTRACT}

\section{Between Business and Patriotism: The Ethnic Economy and Slovenians Outside}

\section{Slovenia}

The article describes various forms and characteristics of ethnic economies, and then focuses on the Slovenian expatriate ethnic community. The author finds that individual ethnic economies have their own specifics depending on their social and educational structure and their historical and political-geographic context. There is a long list of things to do in the Slovenian economy and politics in order to promote the development and implementation of the Slovenian ethnic economy model. However, the term "Slovenian emigrant" is gaining different connotations, as nowadays it can refer to students gaining experience abroad, professionals and daring entrepreneurs. KEY WORDS: Slovenian emigration, ethnic economy, ethnic identity

Doktor politologije, magister kulturne antropologije in diplomirani novinar, sekretar na Uradu Vlade RS za Slovence v zamejstvu in po svetu, Urad Vlade RS za Slovence v zamejstvu in po svetu, Erjavčeva 15, SI-1000 Ljubljana; zvone.zigon@hotmail.com 


\section{UVOD}

Vprašanje »etnične ekonomije« (v njenem najširšem pomenu) se tako v politiki kot znanosti najpogosteje pojavlja med ekonomskimi in socialnimi krizami v izvornih državah. Inštitut za slovensko izseljenstvo in migracije ZRC SAZU v projektu »Etnična ekonomija - izziv ali ovira za gospodarstvo v Sloveniji in EU« izraz »etnična ekonomija« (2012) aplicira predvsem na slovensko okolje. Govori o:

ustanavljanju podjetij delovnih migrantov, ki iščejo niše v obstoječi gospodarski situaciji in so velikokrat povezani z njihovimi socialnimi mrežami ter z njihovimi kulturnimi vzorci, ki so jih prinesli s seboj in se zdaj mešajo s kulturo družbe, kamor so se preselili. Pri prehodu iz družbe v družbo in pri srečevanju z drugačnimi kulturami morajo delovni migranti pokazati veliko mero kreativnosti in inovativnosti, da ostanejo, preživijo, se uveljavijo in tam tudi zaživijo. Poleg tega je pomembno vprašanje, kako tovrstno gospodarstvo vpliva na že obstoječe gospodarske panoge v Republiki Sloveniji. Gre za izziv ali oviro? Temeljno raziskovalno vprašanje je torej, kako migranti z etničnim podjetništvom prispevajo k nastanku in razvoju inovativnih struktur v slovenskem okolju in kako doprinašajo k razvoju in mednarodnemu povezovanju slovenskega gospodarstva. ${ }^{1}$

Enake značilnosti lahko pripišemo tudi slovenskim in vsem drugim migrantom kjerkoli v svetu. Tudi oni so se medsebojno povezovali, v nove kulture prinašali svoje kulturne vzorce in delovne navade ter z njimi - skupaj z drugimi migranti - sooblikovali ali preoblikovali večinsko kulturo. Čeprav so prevladujoče teme o slovenskem izseljenstvu v strokovni literaturi pogosto povezane s socialo, kulturo, šolstvom (ohranjanje jezika) in z umetnostjo, pa se številni raziskovalci v svojih delih dotaknejo tudi ekonomskih oziroma socialnoekonomskih tem. V zadnjem obdobju se etnični ekonomiji na primeru slovenske skupnosti posveča vedno več avtorjev, pri čemer naj - na primeru slovenske skupnosti v Kanadi - v uvodu omenim Mitjo Durnika (2012; 2017).

Besedilo se teme loteva še iz nekega drugega, pravzaprav nasprotnega zornega kota. Etnično ekonomijo oziroma poslovanje na temelju etnične pripadnosti namreč lahko razumemo kot eno od oblik ohranjanja izvorne, primarne etnične identitete. $\mathrm{V}$ primeru slovenske diaspore nas torej zanimajo medsebojna vzročnost, povezanost pa tudi oblike poslovnega povezovanja na temelju etnične pripadnosti, oziroma vsebinska kulturnoantropološka zasnova paradigme »etnične ekonomije«. V nadaljevanju se v manjši meri dotaknem tudi primerov, povezanih s slovensko narodno skupnostjo v sosednjih državah. »Slovenski model« se je v zgodovini vsekakor spreminjal, kar se

1 Iz prijave projekta ISIM ZRC SAZU, spletna stran ISIM. Na to vprašanje v članku odgovarjam z opisom različnih pojavnih oblik slovenske etnične ekonomije. 
mu s hitrimi spremembami v oblikah komunikacije ter v socialni in izobrazbeni strukturi slovenskega izseljenstva (pospešeno!) dogaja tudi danes.

Članek v veliki meri temelji na metodologiji »opazovanja z udeležbo«, saj sem avtor - v vlogi strokovnega delavca na Uradu za Slovence v zamejstvu in po svetu - skoraj vsakodnevno ali vsaj tedensko v stiku s slovenskimi poslovnimi subjekti zunaj meja Republike Slovenije in jim pomagam definirati cilje in načine njihovega uresničevanja, jih seznanjam z možnostmi finančne pomoči za njihovo organizirano delovanje, jih povezujem z gospodarskimi subjekti v Sloveniji, organiziram poslovne konference $z$ osrednjim ciljem njihovega povezovanja z gospodarstvom $v$ matični domovini idr. Ob pomanjkanju širšega nabora literature in virov deskriptivnih podatkov ${ }^{2}$ je moja vpetost $v$ procese ne le spremljanja, ampak celo sooblikovanja slovenskega modela etnične ekonomije ključnega pomena za verodostojnost besedila.

Članek je obenem lahko tudi nastavek za širšo in bolj poglobljeno analizo pričujoče teme. Besedilo se, predvsem zaradi mojih v zadnjih dveh letih močno okrepljenih stikov, nekoliko podrobneje dotika zgolj primera kanadske slovenske gospodarske skupnosti; vendar pa ne gre za sistematični prikaz njenega delovanja (več o njej Durnik 2017). Prav vsak od v nadaljevanju na kratko opisanih primerov (slovenske »etnične ekonomije« zunaj meja RS) je namreč lahko predmet samostojne strokovno-znanstvene obdelave in orisa.

\section{KAJ JE ZA KOGA »ETNIČNA EKONOMIJA«}

Že sama definicija »etnične ekonomije« je izrazito kompleksna in težko ulovljiva. Lahko bi ostali pri eni najbolj temeljnih razlag avtorjev Lighta in Golda (2000), da je etnična ekonomija sestavljena iz skupnosti samozaposlenega oziroma delodajalca, njegovega zaposlenega ter drugih zaposlenih, ki pripadajo isti etnični skupnosti (Durnik, Gombač 2012: 123). Nekateri drugi raziskovalci (Reitz 1980) poudarjajo pomen jezika, ki se uporablja na delovnem mestu, in pa veliko koncentracijo pripadnikov iste etnične skupnosti v določeni industrijski panogi (Zhou, Logan 1989) ali na določenem ozemlju (Sanders, Nee 1987), veliko je tudi razlikovanj med etničnimi podjetniki, poslovneži, inovatorji itd. (Fong, Ooka 2002: 127).

Ob vsej raznolikosti poskusov definiranja lahko kot skupni imenovalec »etnične ekonomije« pod črto zapišemo zgolj pripadnost isti etnični skupini v povezavi $z$ ekonomskimi procesi $v$ različnih družbenopolitičnih in socialnoekonomskih kontekstih. Kljub temu naj se še nekoliko pomudim pri orisih različnih modelov etničnih ekonomij. Light in Gold (Durnik, Gombač 2012: 123) etnično ekonomijo delita na tri kategorije: etnično lastniško ekonomijo, etnično »enklave« ekonomijo in etnično nadzorovano ekonomijo. $V$ prvem primeru ima etnična skupina večinski delež v delniški strukturi večinoma malih in srednjih podjetij, v primeru, da gre za ozemeljsko

2 To v enem svojih zadnjih objavljenih prispevkov na to temo ugotavlja tudi Mitja Durnik (2017: 118). 
zamejeno območje, govorimo o »enklavi«, $v$ »nadzorovani« etnični ekonomiji pa gre že za bolj sofisticiran in širše razpreden sistem, ki nadzoruje tudi javno upravo in v njej in preko nje skrbi za boljši delovni položaj sonarodnjakov.

Vah Jevšnik in Lukšič Hacin (2011: 250) primerjata ameriški in evropski koncept etnične ekonomije in ugotavljata, da sta med seboj zelo težko primerljiva že zaradi različnih političnoekonomskih sistemov (ameriški neoliberalizem versus evropski (neo)korporativizem in socialno regulirani sistemi). V primerjavi z razmerami $\vee$ ZDA, kjer je priseljensko/etnično podjetništvo prepuščeno tržni dinamiki, v Evropi prihaja do intenzivnejšega političnega spodbujanja njegovega razvoja, in to v povezavi s strategijami za učinkovitejšo integracijo priseljencev $v$ t. i. večinsko družbo. Za naše namene je pomembna tudi distinkcija med »etničnim« in »imigrantskim« podjetnikom - »etnični« podjetnik je pripadnik etnične skupnosti, ki je avtohtona oziroma staroselska (kanadski Indijanci, Afroameričani v ZDA), »imigrantski« podjetnik pa je priseljenec in pripada etnični skupnosti, ki se je priselila v določeno državo.

Kot ugotavljata Lukšič Hacin in Toplak (2012: 110), se koncept etnične ekonomije nanaša na vse samozaposlene iz katerekoli etnične ali priseljenske skupine, na delodajalce ter zaposlene iz iste etnične skupine in njihove družinske člane. Etnična ekonomija obstaja, če etnična skupina vzdržuje zasebni ekonomski sektor, v katerem ima večinski lastniški delež, ne glede na to, ali potrošniki so ali niso pripadniki iste etničnosti.

Svojo težo ima tudi pojem »socialne ekonomije« (Jevšnik, Lukšič Hacin 2011: 250; Defourny, Nyssens 2006: 7) v etničnem kontekstu. Govori namreč o samoorganiziranju civilne družbe oziroma v našem primeru etnične skupnosti, ki svoje člane podpira iz solidarnostnih, socialnih razlogov (samopomoč ob pomanjkljivem sistemu socialnega, zdravstvenega, nezgodnega zavarovanja, kritje stroškov pogreba v rudnikih ponesrečenih rojakov ipd.), hkrati pa deluje kot javna neprofitna ustanova. $V$ mislih imam slovenske podporne organizacije, predvsem $v$ ZDA, ki so se hitro razvile v nekakšne zadruge oziroma zdaj zavarovalniške družbe (SNPJ, KSKJ, AMLA - več v nadaljevanju).

Zaradi globalizacije je treba opozoriti tudi na spremembo v razumevanju pojma asimilacije $v$ migracijskih kontekstih. Sodobni izseljenci, tudi če $v$ tujini živijo dalj časa, $z$ odhodom iz matične domovine namreč ne izgubijo več permanentnega stika z njo (Fong, Oka: 428). Pojavi se pojem »transnacionalnost«, ki daje standardnim pojmovanjem socializacijskih procesov novo barvo. Sodobni »transnacionalni« migranti $v$ mnogočem niso primerljivi s starimi izseljenci, saj so večinoma višje izobraženi, strokovnjaki na svojih področjih, obvladajo več jezikov, so visoko »komunikacijsko« usposobljeni. O pozitivnem vplivu globalizacije na »etnično ekonomijo« piše tudi Ivan Light, ki ugotavlja, da v sodobnosti narašča priljubljenost oz. navzočnost »eksotičnih«izdelkov etničnih skupnosti, hkrati pa se veča tudi medsebojna - mednarodna soodvisnost ekonomij, z njo pa narašča pomen bikulturalizma in bilingvizma (Light 2010: 661). 
V kratkem ekskurzu se, za primerjavo, dotaknimo še staroselskega (»aboriginskega«) modela etnične ekonomije, kot ga opisuje Mitja Durnik (Durnik, Gombač 2011: 127). Primer kanadskih Indijancev govori o treh fazah, skozi katere je šla staroselska skupnost Nisišavajašik v severni Manitobi. Ob prvem stiku z belsko civilizacijo in ekonomijo so se znašli v podrejenem položaju, ki se je zapletel z namero gradnje velikih hidroelektrarn. Zaradi možnih usodnih vplivov na njihovo življenjsko okolje so se Indijanci uprli in na te namere niso pristali. Po dolgotrajnem boju so hidroelektrarne prešle $v$ delno lastništvo Indijancev, kar bi na neki način lahko šteli kot njihovo zmago, hkrati pa so «popustili« vplivom njim dotlej tujega ekonomskega sistema in se vanj integrirali. Izhajajoč iz orisanih razmerij, a v nekoliko drugačnem kontekstu, Durnik piše o etnični ekonomiji in slovenskih Romih ter omenja zamisli o romskih podjetjih za reciklažo, čiščenje ipd. (Durnik 2012).

„Vzorčna« primera etnične ekonomije sta lahko položaj kitajskih delavcev v Kanadi in brazilskih v ZDA. Alan Marcus (2011: 57-81) v svojem opisu sodobnega brazilskega izseljenstva $v$ ZDA analizira izobrazbeno in zaposlitveno strukturo migrantov in ugotavlja, da gre v prvi vrsti za zaposlene $v$ storitvenih dejavnostih, kot so gradbeništvo (moški) in čistilni servisi (ženske). Med tistimi, ki ostanejo v ZDA dlje časa ali stalno, se mnogi povzpnejo v svoji branži in postanejo lastniki (čistilnih servisov, gradbenih podjetij). Ugotavlja veliko razliko med uradnimi ameriškimi statistikami, po katerih naj bi bilo v ZDA okoli 300.000 Brazilcev (popis 2007), in neuradnimi številkami, ki se gibljejo celo okrog 1,2 milijona. Zanimivo je, da je brazilska skupnost v ZDA, ki spada med tri največje, zelo poredko omenjana, saj jo mnogi dajejo v isti koš kot »Latinose«, špansko govoreče južnoameriške priseljence (prav tam: 59).

Pomemben je podatek, da naj bi brazilski priseljenci leta 2004 iz ZDA domov poslali skupno okoli šest milijard USD, kar predstavlja en odstotek brazilskega družbenega proizvoda (GDP); povprečna višina mesečnih nakazil je 500 do 1.000 USD. Govorimo torej lahko o etnični ekonomiji z močno solidarnostno "transnacionalno" noto - v prvi vrsti gre za pomoč tistim, ki so ostali doma (prav tam: 61). Avtor poleg tega opaža oziroma navaja opažanje sogovornikov - intervjuvancev, da so Brazilci v ZDA manj »amerikanizirani« kot tisti v sami Braziliji, saj šele v tujini začnejo ceniti svoj etnični izvor (prav tam: 62).

O značilnostih kitajske skupnosti v Kanadi pišeta Eric Fong in Emi Ooka (2002: 125-146). Uvodoma navajata opažanje, da so se v zadnjih 40 letih, predvsem zaradi močno povečanega priseljevanja iz Azije in Južne Amerike, v Kanadi zelo razcvetele etnične ekonomije. Etnično ekonomijo avtorja razumeta kot zaviralca procesov integracije in asimilacije priseljenske etnične skupnosti v večinsko okolje, kar dokazujeta na primeru kitajske skupnosti v Torontu. Ugotavljata, da lahko močna vključenost $v$ etnično skupnost tudi $v$ ekonomskem smislu povzroči zaostanek $v$ navezovanju socialnih stikov $z$ večinskim prebivalstvom in posledično nazadovanje. To se zdi logično, če vemo, da priseljenec delovni in prosti čas preživi bodisi v družinskem podjetju (restavraciji, čistilnem servisu) bodisi v družini. Ves čas govori zgolj kitajsko, saj angleščine praktično ne potrebuje, enako je s socialnimi stiki 
z "zunanjim svetom«. Tak položaj posamezniku sprva sicer lahko olajša prehod v novo družbo, po drugi strani pa ga omejuje pri njegovem napredovanju. To je namreč znotraj etnične skupnosti mogoče zgolj do določene ravni, nakar nastopijo težave zaradi neznanja jezika, nizke izobrazbe in omejenih socialnih stikov in s tem pretoka informacij iz večinskega sistema. ${ }^{3}$

$V$ tem smislu avtorja pišeta o »družinskem« razredu, ki ustreza pričujočemu opisu, in o »neodvisnem « razredu priseljencev. $V$ tem primeru gre za izobražene, kvalificirane delavce ali študente, ki prihajajo na študij v Kanado in nato tam ostanejo. Ti se $v$ večinsko družbo praviloma hitro vključijo in napredujejo po družbeni lestvici. Tako je mogoče opaziti vedno več kitajskih pravnikov, zdravnikov, finančnikov ipd. Iz podatka na spletni strani mesta Toronto, da je po popisu leta 2011 7,6 odstotka populacije kot materni jezik navedlo enega od kitajskih jezikov, je razvidno, da tam živi zelo močna kitajska skupnost (Toronto Backgrounder 2012).

Naslednja od »kombinacij« so lahko tudi slovenske narodne skupnosti v sosednjih državah (v Italiji, Avstriji, Hrvaški, Madžarski). Predvsem v Italiji pa tudi v Avstriji je ta dobro gospodarsko organizirana, $v$ njej pa se prepletajo vse naštete oblike etnične ekonomije. Posebnost je nemara ta, da imajo v vseh štirih državah, ki obkrožajo Slovenijo, posebno vlogo t. i. »krovne« ustanove, neke vrste gospodarske zbornice, katerih člani so podjetniki slovenskega rodu. ${ }^{4}$ Gospodarska organiziranost slovenske narodne skupnosti vpliva na njeno ekonomsko moč, ta pa na etnično samozavest pripadnikov »manjšine«, ki je vsakodnevno izpostavljena pritiskom večinske kulture. ${ }^{5}$

\section{"SLOVENSKA«ETNIČNA EKONOMIJA}

Kitajci v Kanadi, Brazilci v ZDA, Romi v Sloveniji, ... ${ }^{6}$ mogoče so neštete kombinacije, ki vsaka zase ponuja svoj »model« etnične ekonomije. Slovensko izseljenstvo se zaradi neprimerljivo manjših številk in izrazite raznolikosti bistveno razlikuje od večine naštetih modelov. Na značilnosti slovenske etnične ekonomije v izseljenstvu,

3 Light (2010: 655) ugotavlja, da je v nekaterih »etničnih« podjetjih kar 2/3 osebja neplačanih družinskih članov ali lastnikov. Isti avtor (2004: 385-386) piše tudi o pogostih vzorcih socialne zapostavljenosti članov takšne etnične ekonomije, saj pogosto niso prijavljeni lokalnim oblastem, ne oni ne lastniki podjetja ne plačujejo davkov, socialnega, zdravstvenega zavarovanja ipd.

4 O tem več v nadaljevanju - gre predvsem za Slovensko deželno gospodarsko zvezo $v$ Trstu, Slovensko gospodarsko zvezo v Celovcu pa tudi pretežno novi sorodni ustanovi v Monoštru (Madžarska) in na Reki (Hrvaška).

5 O tem piše Sonja Novak Lukanovič z Inštituta za narodnostna vprašanja. Poudarjeno tudi v referatu Gospodarstvo in identiteta manjšine na konferenci Etnična ekonomija in Slovenci zunaj RS (Lukanovič 2012).

6 Soavtorji Light, Sabagh ... (1993: 581) pišejo celo o etničnih podskupinah znotraj neke etnične ekonomije oziroma etnične skupnosti. Kaj takega na primeru slovenske skupnosti zaradi vse premajhnih številk vsaj v ekonomskem smislu skoraj ni mogoče, čeprav smo tudi v slovenski diaspori pogosto priča (predvsem politični) razdeljenosti - a ta korenini v vzrokih in obdobjih izseljevanja. 
če o njej sploh lahko govorimo, vpliva dejstvo, da so se Slovenci s svojega etničnega ozemlja izseljevali v različnih zgodovinskih obdobjih in iz zelo različnih vzrokov.

Da bi slovenski pa tudi katerikoli drugi »model« lažje razumeli, posezimo nekoliko globlje, $\mathrm{k}$ vprašanjem same etnične identitete. Poti in načini ohranjanja izvorne slovenske etnične identitete med izseljenskimi skupnostmi po svetu so seveda različni. V preteklih raziskavah sem za razumevanje občutenja večplastnosti posameznikove osebne in etnične identitete $v$ izseljenstvu uporabil lastni model gibljive kvalitativne lestvice pojavnih oblik in ravni identitete pri pripadnikih generacij potomcev slovenskih izseljencev. Pozicija »kategorij« nikakor ni fiksna, ravni se med seboj prepletajo in zamenjujejo, elementi ene kategorije so lahko navzoči tudi pri drugi itd. Naštel sem devet kategorij, od zgolj zavedanja o etničnem izvoru preko občasnega ali rednega sodelovanja v organizirani zdomski ali izseljenski skupnosti, obiskovanja izvorne domovine, pa do odločitve o preselitvi - kot povratku ali kot izselitvi v deželo staršev. V primeru ali izseljenstva ali potomcev slovenskih izseljencev, že rojenih v neslovenski večinski družbi, govorimo o več ravneh etničnega samozavedanja (Žigon 1998: 104-106).

\section{Ravni etničnega samozavedanja ${ }^{7}$}

Etnična identiteta $v$ izseljenstvu je odvisna tako od specifične pozicije subjekta kot generacijske pripadnosti in z njo povezane primarne in sekundarne socializacije. Posamezniki iz prve generacije so bili socializirani v svojem izvornem etničnem in kulturnem okolju, zato resocializacijo, ki so ji bili izpostavljeni ob stiku z imigracijsko družbo, razumemo kot »naslednji« proces - govorimo torej o zaporedju. Člani izseljenske skupnosti, rojeni v imigracijski družbi, pa so izpostavljeni različnim oblikam dvojne socializacije, govorimo torej o vzporednosti. Dvojnost, vzporednost socializacije pride bolj do izraza ob večji doslednosti pri ohranjanju primarne kulturne identitete $v$ družini, manj izrazita pa je, če starši že podlegajo vplivom asimilacije, če npr. doma dovolijo uporabo dominantnega jezika, če ga sami govorijo, v mešanih zakonih, če sta si v tem akulturacijskem momentu udeleženi kulturi podobni (Žigon 2001: 33).

Gibljiva lestvica ravni etničnega samozavedanja te razvršča glede na to, kako intenzivno posameznik občuti (svojo) primarno etnično pripadnost:

1. Identifikacijska identiteta - zgolj golo zavedanje ali védenje, da posameznik izvira iz določene države; na tej ravni je pravzaprav velika večina asimiliranega izseljenstva.

2. Odprtost - zavestno samooznačevanje za potomce izvorne kulture; občasno izrazijo željo po vzpostavitvi tesnejšega stika z njo.

3. Folklorno-simbolna identiteta - občasno pasivno spremljanje dogodkov v skupnosti; vanjo spada razmeroma velik del izseljenske populacije.

4. Klubska identiteta - s poudarjeno pripadnostjo klubu, ki pa včasih nima skoraj nič z etnično pripadnostjo, saj se je lahko »nalezejo« tudi neslovenski člani kluba.

7 Zvone Žigon: Otroci dveh domovin (1998: 104-106). 
Vsi aktivni v slovenski skupnosti so pripadni svojim klubom in je njihova pripadnost več kot le klubska.

5. Želja po pridobitvi slovenskega državljanstva in učenju jezika - izjemno je porasla $v$ zadnjih letih pri pripadnikih tretje generacije ... gre celo za materialne koristi (potni list EU), večinoma pa za simbolno identifikacijo s Slovenijo.

6. Mobilizacijska identiteta - bistvena za aktiviranje posameznika na način, da se redno udeležuje organiziranih oblik »slovenstva« ali celo sam sodeluje - v kuhinji, zboru, ...

7. Obiskovanje, redni stiki z izvorno domovino - ta kategorija sicer ni prvi pogoj ali odraz siceršnje aktivnosti v društvih, je pa izjemnega pomena za razumevanje in doumevanje izvorne domovine.

8. Govorjenje in gojenje jezika staršev - brez znanja in razumevanja jezika globlje doumevanje izvorne domovine ne more biti enako kot tam, kjer jezik še živi. Po drugi strani pa ni mogoče trditi, da z izginotjem jezika izgine tudi pripadnost izvorni kulturi - le da je na drugi ravni.

9. Odločitev o preselitvi v izvorno domovino - za tovrstno odločitev sta potrebna vsaj dva dejavnika: izjemno visoka stopnja pripadnosti izvorni kulturi ter ustrezni ekonomski dejavniki odbijanja in privlačenja. Dejstvo, da Slovenija ni ekonomsko tako zelo varna in privlačna kot nekatere druge države Zahodne Evrope, pa se kljub temu nekdo odloči za preselitev, dokazuje zelo visoko raven etnične identifikacije s slovensko kulturo. Z drugimi besedami, v tehtanju racionalnih in neracionalnih, subjektivnih dejavnikov prevladajo slednji.

Dejavnik »etnične ekonomije« oziroma razmišljanje o udejanjanju »slovenskosti« tudi skozi ekonomske perspektive je na gibljivi lestvici lahko skupaj s katerokoli od naštetih ravni. Lastne izkušnje kažejo, da se nekateri potomci slovenskih izseljencev, ki o Sloveniji ne vedo skoraj nič, ne znajo jezika, ne sodelujejo v izseljenskih kulturnih in drugih ustanovah idr., "aktivirajo " prav ob vprašanjih gospodarstva, turizma in sorodnih tem. ${ }^{8}$ Tudi sama izseljenska društva, ki iščejo nove načine pritegovanja mlajših generacij oziroma od skupnosti oddaljenih rojakov, skušajo v svoje dogodke, načrte delovanja ipd. vključevati tudi predstavitve slovenskih gospodarskih, turističnih in ob tem tudi kulinaričnih značilnosti.

Izhajajoč iz naštetih in na kratko orisanih kakovostnih ravni izražanja etnične identitete lahko razmišljamo še o novih načinih in poteh. Najvidnejša oblika vzdrževanja stika z izvorno kulturo so sicer res pretežno kulturne, verske in družabne dejavnosti, ne smemo pa pozabiti, da so imela že od samega začetka masovnega izseljevanja usodno vlogo tudi tako imenovana »bratska« združenja, ki so na temelju medseboj-

8 Kot generalni konzul RS v Clevelandu sem leta 2006 ustanovil Ameriško-slovensko poslovno združenje (American Slovenian Business Association). Ker je bilo vabilo na prvi dogodek objavljeno tudi v ameriških (neizseljenskih) medijih, se je nanj odzvalo nekaj uspešnih posameznikov slovenskega rodu, čeprav nekateri med njimi sploh niso vedeli, da v mestu obstaja močna in številčna slovenska skupnost (David Perse, takrat direktor zasebne klinike Lutheran Hospital, Ray Marvar, takrat član upravnega odbora slovite Cleveland Clinic, Dick Russ, eden vodilnih televizijskih voditeljev kanala Channel 3 idr.). 
ne solidarnosti skrbela za eksistenčni minimum svojih članov v primeru delovnih nesreč, bolezni in smrti. Iz »podpornih jednot“ (ameriški KSKJ, SNPJ, AMLA) (Klemenčič 1995: 178-218) in kreditnih zadrug (buenosaireška Sloga) so sčasoma prerasle v (tudi) kulturno-prosvetne ustanove in so tako za širok del slovenskega izseljenstva v ZDA (4., 5. generacija) pravzaprav edina oblika dojemanja - udejanjanja slovenstva. $\mathrm{Na}$ po svoje banalen način se slovenska etnična identiteta $v$ tem primeru zrcali $v$ kreditno-hranilnični bančni kartici. Sliši se neromantično, a ob razumevanju naravnih zakonitosti asimilacije bodo morda prav tovrstni modeli - seveda ob ustreznih modifikacijah glede na trenutno stanje - predstavljali najbolj razširjeno obliko ali pot do neke konstantne ravni ohranitve izvorne kulture. ${ }^{9}$ Tako smo pristali v polju »etnične ekonomije«. Na kratko orisane značilnosti podpornih organizacij oziroma družb (predvsem) v ZDA so pravzaprav najvišje oblike tovrstne »organiziranosti« slovenske skupnosti. V vseh drugih primerih namreč zaradi majhnosti slovenskih izseljenskih skupnosti - sploh v primerjavi z modeli velikih skupnosti, kot sta kitajska skupnost v Torontu ali brazilska $v$ ZDA - lahko govorimo zgolj o posamičnih primerih ekonomskega sodelovanja na etničnih temeljih.

Kar pa ne pomeni, da samo vprašanje ni vseprisotno. Obenem z naštetimi kvalitativnimi ravnmi etničnega samozavedanja namreč »teče« tudi polje etnične ekonomije. Tako v stikih s slovenskimi izseljenci in z njihovimi potomci v Argentini, Urugvaju, Braziliji, Južni Afriki, Keniji, Kanadi, ZDA, Nemčiji, Italiji, Avstriji, Luksemburgu itd. kot $v$ številnih osebnih stikih, navezanih med dalǰsim bivanjem v slovenski skupnosti v Avstraliji in ZDA, sem namreč lahko opazil določeno pripravljenost za manifestiranje slovenske identitete skozi polje ekonomije $v$ najširšem pomenu besede. A od hranilniško-zavarovalniških družb z izvorom v solidarnostnih združenjih do morebitnega gospodarskega sodelovanja z izvorno domovino je še daleč.

Kot eno od vmesnih stopenj je treba omeniti prakso, ki je bila in je še vedno uveljavljena pri marsikaterem slovenskem podjetju v tujini. Slovenski izseljenec, migrant z lastnima delom in sposobnostjo uspe, njegovo podjetje se širi in potrebuje nove delavce. Iz izrazito solidarnostnih in domoljubnih razlogov sprva skoraj avtomatsko zaposli soizseljence. Ker jim zaupa kot ljudem in delavcem, ker so do nedavnega delili isto usodo. Ta model sem na različne načine in iz različnih zornih kotov $v$ besedilu orisal tudi na primerih drugih etničnih skupnosti. Slovenci so v vseh državah brez izjem znani kot zelo delavni, vestni, kakovostni in zanesljivi delavci. To ravnanje bi

9 Predsednik KSKJ (nastali leta 1894) Rudolph Krašovec v uvodniku letnega poročila člane nagovarja na zelo zgovoren način: »Tako kot velike Združene države, v katerih živimo, je bila tudi naša KSKJ Life ustanovljena iz ljudi in za ljudi, ki so se sem priselili iz domovine Slovenije. Naša ustanova je nastala zato, da bi povezala tiste s skupnim kulturnim izročilom in da bi družine obvarovala pred tragedijami, ki so se $v$ dobi zgodnje industrializacije pogosto dogajale. Naši ustanovitelji so bili delavci v rudnikih in železarnah, ki so pomagali sooblikovati infrastrukturo te nove države, $v$ kateri so se naselili. Nesreče pri delu so bile zelo pogoste. In takrat je KSKJ zaščitila vdove in otroke ...« (KSKJ Life 2015: 3). Čeprav so člani lahko tudi Neslovenci, KSKJ ohranja pripadnost slovenskim koreninam, kar med drugim izkazuje tudi z novo grafično podobo, ki vsebuje stilizirano obliko Triglava (prav tam: 1). Na podoben način deluje tudi sorodna, po nastanku (1904) sicer progresivna SNPJ. 
lahko opisali v smislu »prijetno s koristnim«. Zgolj v redkih primerih je rojak pri rojaku zaposlen samo zato, ker sta rojaka, tudi če za delo v resnici ni sposoben; to bi lahko umestili med napol karitativne razloge. Zanimivo je, da marsikatero takšno (»slovensko«) podjetje poleg Slovencev zaposluje tudi delavce iz držav nekdanje skupne države (Jugoslavije). Tovrstno zaupanje temelji na sosedstvu, sorodnosti jezika in deloma tudi delovnih navad.

Zaradi svoje majhnosti slovenske skupnosti dejansko ne morejo delovati po vzoru kitajske ali brazilske, dejansko pa »naravno« poslovno sodelovanje v slovenskem primeru nadomeščajo organizirani poskusi poslovnega povezovanja. Tako so se $v$ preteklosti v izseljenstvu že ustanavljale slovenske poslovne skupnosti. ${ }^{10}$

\section{SLOVENSKI POSLOVNI SUBJEKTI V TUJINI}

Na drugem koncu časovne premice - oziroma izključno $v$ današnjem času - so sodobna poslovna združenja in klubi, ki si zelo konkretno prizadevajo za spodbujanje gospodarskih povezav s Slovenijo. Sam ločim dve kategoriji: slovenske poslovne klube in slovenska poslovna združenja.

V Slovenskih poslovnih klubih se zbirajo predstavništva slovenskih podjetij in podjetja matične države, ki poslujejo s Slovenijo. Njihovi namen in cilji so pomoč slovenskim podjetjem pri navezovanju poslovnih stikov, promocija slovenskega gospodarstva, medsebojne gospodarske izmenjave ter konkretni projekti, od soorganiziranja predstavitev na gospodarskih sejmih do pomoči pri prijavljanju na javne razpise in sodelovanja pri pripravi poslovnih konferenc in obiskov gospodarskih delegacij iz Slovenije oziroma v Slovenijo.

Razmeroma močno pomoč slovenske države, ki jo izvaja Ministrstvo za gospodarstvo in tehnološki razvoj RS (preko agencije Spirit, nekoč Japti), morajo upravičiti s konkretnimi rezultati, z ustvarjanjem poslovnih priložnosti, dogodkov promocije slovenskega gospodarstva ipd. Leta 2017 je Spirit sofinanciral 14 takšnih klubov v 12 državah, še nekaj pa jih zaradi neizpolnjevanja kriterijev ali neprijave na razpis ostaja

10 Urad Vlade RS za Slovence v zamejstvu in po svetu (USZS) v zadnjih letih opaža porast tako nastajanja novih združenj, klubov ipd. z razločno izraženimi cilji delovanja pri spodbujanju gospodarskega sodelovanja med Slovenijo in državo, v kateri združenje deluje, kot interesa za njihovo vzpostavitev. Tako so od leta 2014 nova poslovna združenja nastala v Münchnu, Nürnbergu, Luksemburgu, Sydneyu, Bratislavi, Milanu, podobne zamisli se nastajajo v Frankfurtu, Stuttgartu in gotovo še kje. 
brez finančne pomoči. Med slednjimi so predvsem slovenska "poslovna združenja«, o katerih več v nadaljevanju. ${ }^{11}$

Omenjeni model ima z opisano »etnično ekonomijo« v številnih primerih praktično zelo malo skupnega, saj gre na neki način za načrtovano dejavnost vladnih organov Republike Slovenije za prizadevanje pri mednarodnem odpiranju slovenskega gospodarstva. »Etnično « je tu prisotno zgolj v primeru, da so v sodelovanje s poslovnimi klubi vključeni podjetniki in poslovneži slovenskega rodu, ki to delajo tudi iz subjektivnega, »domoljubnega« vzgiba. Resnici na ljubo pa je takih kar nekaj - večinoma so to slovenski poslovneži, ki so v neko državo prišli zgolj z namenom vzpostavitve poslovnih vezi oziroma priložnosti.

Kot posebno kategorijo med poslovnimi klubi lahko navedemo Slovensko deželno gospodarsko zvezo (SDGZ) v Trstu ter Slovensko gospodarsko zvezo (SGZ) in Alpe-Jadran center (AACC) v Celovcu. SDGZ in SGZ delujeta že desetletja in povezujeta slovensko zamejsko poslovno skupnost, vedno bolj pa delujeta tudi čezmejno. Izstopa SDGZ iz Trsta, ki zaposluje okoli 40 ljudi, je vključena v najpomembnejša italijanska gospodarska združenja in je v operativnem smislu stična točka med italijanskim, zamejskim in slovenskim gospodarstvom.

Po poti SDGZ gresta tudi SGZ, ki ima zaenkrat zgolj dve redno zaposleni osebi, ter AACC center v Celovcu, ki deluje izrazito na zasebno pobudo (in je o njem razmeroma malo podatkov). Urad za Evropo, delujoč na Reki (Hrvaška), se tudi po nekaj letih delovanja ne uspe razviti v resnični poslovni klub; uspešnejše se trenutno zdijo ločene pobude iz Gorskega Kotarja, kjer je, v sodelovanju z Uradom za Slovence v zamejstvu in po svetu in drugimi partnerji, v pripravi projekt oblikovanja slovenske vzorčne kmetije. Razvojna agencija Slovenska krajina v Monoštru (Madžarska) dejavno pridobiva sredstva iz naslova EU in sodeluje na več projektih pretežno kmetijske narave (leta 2015 vzpostavljena vzorčna kmetija ipd.).

Vsi našteti delujejo na območjih, kjer v sosednjih državah živi slovenska narodna skupnost. Štiri od petih naštetih ustanov vsaj deloma redno podpira tudi slovenska država, od organizacijskega in vsebinskega sodelovanja do neposrednega sofinanciranja nekaterih projektov preko javnih razpisov Urada Vlade RS za Slovence v zamejstvu in po svetu; uveljavlja se tudi sodelovanje pri črpanju sredstev Evropske unije za spodbujanje čezmejnega sodelovanja.

11 Seznam prejemnikov sredstev iz Javnega razpisa za sofinanciranje izvajanja dejavnosti slovenskih poslovnih klubov v tujini v letu 2017: Slovenian American Business Association S-ABA (ZDA): 21.696 EUR; Slovensko deželno gospodarsko združenje (Trst): 37.821 EUR; Nekomercialno partnerstvo Uljanovsk, regionalno združenje izvoznikov in uvoznikov o razvoju zunanje gospodarske dejavnosti (Rusija): 29.612 EUR; Društvo in poslovni klub Triglav - Rysy (Poljska): 20.816 EUR; Društvo slovensko-madžarskih poslovnežev: 12.000 EUR; Rusko-slovenski poslovni klub Tolyatty: 38.114 EUR; Poslovni klub slovensko-hrvaških gospodarstvenikov: 19.455 EUR; Slovenska gospodarska zveza v Celovcu: 37.465 EUR; Slovenian Business and Research Association, Bruselj: 21.821 EUR; Slovenački poslovni klub Beograd: 38.994 EUR; Luxemburg Slowenien Business Club: 30.785 EUR; Canadian Slovenian Chamber of Commerce: 30.850 EUR; Euro Alliance Consulting LLC, Slovenian Busines Club Kosovo: 39.580 EUR; Slovenian Business Club Zambia Slovenia CO: 21.109 EUR (Spirit Slovenija 2017). 
V tem kontekstu torej govorimo o spodbujanju čezmejnega gospodarskega sodelovanja predvsem med slovenskimi zamejskimi podjetniki in poslovneži ter zainteresiranosti matične države za gospodarsko močno manjšinsko skupnost $v$ sosednjih državah. Ekonomska suverenost se torej kaže kot logična podlaga za kulturno in etnično samozavest - ta povezava velja za manjšinske narodne skupnosti v sosednjih državah, ${ }^{12}$ ne pa tudi za izseljenske skupnosti.

Izseljenska poslovna združenja so pojem, oznaka, ki ga v slovenskem poslovnem in družboslovnem izrazoslovju praktično še ni. To so združenja, v katerih se združujejo podjetniki in poslovneži slovenskega rodu. Zakaj? Konkretnih poslovnih koristi od tega (večinoma, za zdaj) niti nimajo, druži jih le subjektivna pripadnost izvorni domovini. Njihove (ali obojestranske, torej tudi za Republiko Slovenijo) morebitne konkretne koristi so oziroma bi lahko bile: medsebojno poslovno povezovanje, vzpostavljanje poslovnih stikov s slovenskimi podjetji, pomoč pri promociji slovenskega gospodarstva s kontakti, z asistenco pri organiziranju poslovnih dogodkov, obiskov gospodarskih delegacij ipd. Zanje je značilno, da večina ne »zmore« kriterijev oziroma tempa in profesionalnosti, kot jo agencija SPIRIT Slovenija zahteva od slovenskih poslovnih klubov, ter da so kot izrazito prostovoljna in prostočasna dejavnost razmeroma ohlapno organizirana in šibko delujoča.

Konotacije $v$ primeru slovenskih etničnih poslovnih skupnosti oziroma združenj v izseljenski situaciji so drugačne od tistih v zamejstvu. "Politično-strateškega« interesa matične države tu ni, vsaj ne v takšni meri kot v primeru zamejstva. Vsekakor pa obstaja ekonomski ter širši, splošnejši interes po večjem povezovanju slovenskih poslovnežev in podjetnikov $v$ svetu z matično domovino.

Ker se povečuje izseljevanje izobraženih in podjetnih posameznikov iz Slovenije, ${ }^{13}$ lahko - če govorimo o oblikovanju izseljenskih poslovnih združenj - govorimo

12 O pomenu slovenske etnične ekonomije za narodno samozavest pa tudi za dobesedno fizično preživetje slovenske narodne skupnosti kot take zgovorno priča obsežna monografija Milana Pahorja Slovensko denarništvo v Trstu (1989). Ta sicer orisuje nastanek, razvoj in delovanje denarnih zadrug, hranilnic, posojilnic in bank med letoma 1880 in 1918, vendar se pomen gospodarske samozadostnosti v primeru avtohtone $z$ leti in geopolitičnimi spremembami ni zmanjšal. Isti avtor tako piše o gospodarskih dejavnosti v deželi Furlaniji-Julijski krajini med letoma 1848 in 1998 (Pahor 1998). - Zgovoren je stavek iz spremne besede publikacije o denarništvu: »Tržaška hranilnica in posojilnica je bila tesno povezana s kulturnim in narodnostnim delovanjem Slovencev na Tržaškem ... (prav tam: 5). - O pomenu in sploh konceptu vpliva gospodarstva na obstoj narodne skupnosti pa govori uvodnik druge knjige: »... Doseganje gospodarskih ciljev je dovolj za človeka, ne pa za narod. In tako je prav iz vrst podjetnikov in njihovih organizacij, združenj in zvez prišla največja pomoč za gradnjo kulturnih in rekreacijskih sedežev ter šol. Zrasel je Narodni dom pri Sv. Ivanu (1902), Narodni dom v Barkovljah (1897), Trgovski dom v Trstu (1904) in seveda Narodni dom v Trstu (1904) ter drugi. Kultura se je razvijala na trdni gospodarski osnovi« (prav tam).

13 Razprave o tem, predvsem o novodobnem izseljevanju slovenskih raziskovalcev in znanstvenikov, je prispevala dr. Breda Mulec v prispevkih na temo kroženja možganov (Mulec 2012). Kljub precejšnjemu povečanju še vedno ne moremo govoriti o množičnem izseljevanju. Statistika je pogosto stvar interpretacije ali celo manipulacije, saj je laže navajati podatke o izselitvah, pri tem pa ne upoštevati podatkov o priselitvah v Slovenijo, razločevati med začasnimi in stalnimi izselitvami, študijem v tujini ipd. 
o procesu, ki je šele na začetku, aktivno sodelovanje slovenske države pa ga lahko okrepi. ${ }^{14}$ Kot posebno obliko sodelovanja matične države lahko razumemo njena gospodarska in diplomatska predstavništva, katerih naloga je tudi delo z lastno etnično skupnostjo in vsemi možnimi različicami »etnične ekonomije«. ${ }^{15}$

O resničnih začetkih poslovnega sodelovanja izseljenskih podjetnikov z matično domovino lahko govorimo v letih 1990 in 1991, ko so mnogi premožni rojaki prispevali sredstva v podporo slovenski politični demokratizaciji, državni osamosvojitvi ter mednarodnemu priznanju, ${ }^{16}$ nekateri so vlagali v obujeni desnosredinski dnevnik Slovenec, precej pa je bilo tudi poskusov investiranja in gospodarskega sodelovanja s podjetji v Sloveniji. Še vedno prevelike razlike v ekonomskih in zakonskih sistemih, birokratske ovire v Sloveniji pa tudi subjektivno preveliko pričakovanje izseljencev in po drugi strani svojevrstna »diasporafobnost« oz. strah slovenskega gospodarstva in politike pred konkurenco iz vrst slovenskih podjetnikov iz tujine so botrovali temu, da se je večina poskusov končala z razočaranjem. Nesojeni investitorji in poslovni partnerji iz vrst slovenske diaspore pa so se večinoma trajno poslovili od podobnih načrtov. Hkrati ali pa šele $v$ zadnjih letih so se $v$ nekaterih večjih središčih slovenskega izseljenstva oblikovali »gospodarske zbornice« in podobna združenja. Danes tako v svetu poznamo:

1. Kanadsko-slovensko gospodarsko zbornico (Toronto);

2. Slovensko-ameriški poslovni klub (SABA - Cleveland);

3. Avstralsko-slovensko gospodarsko zbornico (Sydney);

4. Poslovni klub ICS (Internationaler Club Slovenia e. V.) (München);

5. Slovensko-bavarsko združenje z gospodarsko sekcijo (München);

6. Business Council Slovenia (Düsseldorf);

7. Poslovni klub GeriS e. V. (Nürnberg);

8. Klub slovenskih in slovaških poslovnežev Slo-Slo (Bratislava);

9. SloLux, Slovensko društvo v Luksemburgu;

10. Slovensko poslovno združenje na Nizozemskem;

11. Poslovni klub ECE na Kanarskih otokih (Španija); ${ }^{17}$

12. Slovenski poslovni klub v Milanu. ${ }^{18}$

14 O vlogi slovenske države v tem kontekstu se je 4. 7. 2012 razpravljalo na posvetu Etnična ekonomija in Slovenci zunaj RS (Žigon 2012).

15 O vlogi slovenskih diplomatskih predstavništev v izseljenski skupnosti več v: (Žigon 2011: 179-200). Generalni konzulat RS v Clevelandu je leta 2008 spodbudil ustanovitev neformalnega združenja Cleveland Slovenian Business and Professional Association, nato pa leta 2012 formalno ustanovitev poslovnega kluba American Slovenian Business Association.

16 Draga Gelt (2011) podrobno opisuje tovrstno delovanje slovenske skupnosti v Avstraliji, številni opisi pa obstajajo tudi za slovenske skupnosti v drugih državah, predvsem v ZDA, Kanadi, Argentini in Veliki Britaniji.

17 Vir: Spletna stran Urada Vlade RS za Slovence v zamejstvu in po svetu - seznam slovenskih organizacij po svetu; o dejavnosti kluba na Kanarskih otokih Urad nima svežih informacij.

18 Klub je bil 23. 11. 2017 v Milanu v navzočnosti avtorja članka, ministra za Slovence v zamejstvu in po svetu Gorazda Žmavca, vodje gospodarskega predstavništva RS v Milanu Zorka Pelikana idr. prvič javno predstavljen. 
Urad Vlade RS za Slovence v zamejstvu in po svetu si prizadeva »etnično ekonomijo« oziroma sodelovanje s slovensko poslovno skupnostjo zunaj RS sooblikovati z organizacijo poslovnih konferenc s skupnim naslovom Mednarodno poslovanje lokalnega podjetništva. Zadnji dve konferenci sta potekali pod naslovom: Slovenska podjetnost kroži prek meja. Tako je Urad med letoma 2012 in 2017 pripravil več poslovnih konferenc. V Grosupljem (junij 2012) so se - mnogi prvič - srečali slovenske poslovne organizacije iz zamejstva in slovenske lokalne obrtne in gospodarske zbornice in podjetja. Na naslednjih konferencah (Ptuj - oktober 2012, Idrija/Cerkno - april 2013, Terme Čatež - oktober 2013, Koper - maj 2014, Bled - november 2014, Murska Sobota - april 2015) so se poleg zamejskih gospodarskih ustanov predstavili tudi slovenski poslovno naravnani klub z Bavarske, več slovenskih podjetnikov iz Nemčije in severne Italije, častni konzuli RS iz Dresdna, Ženeve in Milana, v Čatežu pa tudi slovenski poslovni klubi in ekonomski svetovalci na ambasadah RS $v$ državah nekdanje SFRJ. Leta 2016 je bila konferenca prvič organizirana zunaj meja RS, natančneje v Münchnu. Udeležilo se je je cca. 30 podjetnikov iz Slovenije, za katere je prevoz organiziral Urad, ter okoli 25 podjetnikov slovenskega rodu, delujočih v Nemčiji. ${ }^{19}$ Zadnja takšna konferenca je bila 31. 5. 2017 v Vili Vipolže pri Novi Gorici, med skupno 118 udeleženci pa so bili tudi slovenski podjetniki iz Nemčije, Italije, Avstrije, Češke, Slovaške, Luksemburga, Avstralije, Kanade idr. Še zlasti dragocen je bil vsakokratni match-making oziroma 'srečanja ena-na-ena' v drugem delu konferenc. ${ }^{20}$

Posebej je treba omeniti zelo dejavno Kanadsko-slovensko gospodarsko zbornico, ki ob močni organizacijski in finančni podpori častnega generalnega konzula in poslovneža slovenskega rodu Johna Doma dejavno sodeluje s slovenskim gospodarstvom. Junija 2017 je tako organizirala gostovanje delegacije slovenskih podjetij in turističnih agencij ter Slovenske turistične organizacije na predstavitvi v Torontu in Ottawi (ob 25-letnici diplomatskih odnosov med državama in 150-letnici kanadske državnosti). ${ }^{21}$ Zbornica je med vsemi naštetimi najbolje organizirana. Leta 2011 je izdala poslovni imenik, v katerem je navedenih 86 podjetij - oglaševalcev, ob tem pa telefonske številke 3.156 članov zbornice (Canadian Slovenian Chamber of Commerce 2010).

Za skoraj vse naštete bi lahko veljala skupna ugotovitev, da je resnična poslovna korist sekundarnega pomena. Čeprav ni nekoristno, ima tovrstno druženje predvsem družaben, nostalgičen in torej subjektiven, neracionalen pomen. Pripadniki

19 Navzoči so bili tudi minister za Slovence v zamejstvu in po svetu Gorazd Žmavc, predsednik Obrtne zbornice Slovenije Branko Meh idr.

20 Poročila o konferencah na spletni strani Urada: http://www.uszs.gov.si/si/znanost_mladi_gospodarstvo/gospodarstvo/aktivnosti_v_letu_2016/poslovna_konferenca_v_muenchnu/

21 Mitja Durnik v svojem zadnjem članku na temo etnične ekonomije omenja prav primer slovenske skupnosti v Kanadi. Piše o vlogi, ki jo je kljub svoji relativni majhnosti imela slovenska skupnost pri gospodarski rasti države priseljevanja. Razpravlja pa tudi o vplivu najnovejše skupine priseljencev iz Slovenije, ki se je v Kanado priselila med zadnjo ekonomsko krizo in po njej. Kanadsko-slovenska gospodarska zbornica sicer šteje čez sto članov iz Kanade in tudi nekaj iz Slovenije (Durnik 2017). 
iste etnične skupnosti se v opisanih primerih novodobne slovenske ekonomske migracije družijo na popolnoma drugačnih temeljih, kot jih na primerih različnih velikih etničnih ekonomij opisujejo številni, v prvem delu besedila našteti avtorji. Razlikujejo se tudi od »starega« modela slovenske etnične ekonomije iz obdobja delovanja solidarnostnih hranilniških ustanov v začetku 20. stoletja (in v primeru KSKJ v ZDA že ob koncu 19. stoletja - ta organizacija je bila namreč ustanovljena že leta 1894). Dejstvo, da smo v obdobju globalizacije, ki prinaša prednosti večjezičnosti, večje socialne in navsezadnje tehnološke povezanosti in večje ekonomske soodvisnosti ekonomskih partnerjev in nacionalnih ekonomij, prispeva k oblikovanju nove paradigme sodobne slovenske etnične ekonomije. ${ }^{22}$ Ta temelji predvsem na individualnih, pogosto izrazito osebnih, vsekakor pa zaenkrat še ne dovolj raziskanih povezavah z matično domovino. Medsebojnega povezovanja na temelju poslovne ali socialne koristi je zelo malo, saj gre predvsem za navezovanje socialnih stikov z rojaki.

Kot soustvarjalca slovenskega modela etnične ekonomije - $v$ luči povezovanja slovenskega gospodarstva zunaj meja Republike Slovenije z matično domovino lahko razumemo tudi Svetovni slovenski kongres. Ta vsako leto organizira dve konferenci, na katerih sodelujejo pripadniki slovenske skupnosti iz izseljenstva oziroma zamejstva iz različnih strok - od podjetnikov do znanstvenikov, raziskovalcev, arhitektov, pravnikov idr. ${ }^{23}$

Vse pomembnejšo vlogo pridobivata tudi novi združenji, in to ASEF (American Slovenian Educational Fundation, San Francisco), ki spodbuja študijske izmenjave krajša gostovanja slovenskih študentov pri slovenskih profesorjih v tujini in potomcev slovenskih izseljencev na univerzah v Sloveniji, ter VTIS (Društvo v tujini izobraženih Slovencev), ki združuje že več kot tisoč sedanjih in nekdanjih študentov. Obe ustanovi se skušata tesno povezovati tudi z gospodarstvom.

22 O pozitivnih vplivih globalizacije ali natančneje interneta na medsebojno povezovanje slovenske diaspore več v: (Žigon 2003). V referatu (že takrat) ugotavljam, da imajo skoraj vse slovenske organizacije po svetu svojo spletno stran, da se rojaki z matično domovino lahko vsakodnevno povezujejo po elektronski pošti ali Facebooku ter Skypu. Za generacije potomcev slovenskih izseljencev je odločilnega pomena tudi dejstvo, da mlajše generacije v Sloveniji dobro obvladajo angleščino, kar dodatno lajša komunikacijo.

Zborniki Svetovnega Slovenskega kongresa v obdobju 2000-2017. 


\section{SKLEP}

Pričujoče besedilo opisuje različne pojavne oblike splošnih etničnih identitet in ekonomij ter njihovih pojavnih oblik pri slovenski narodni skupnosti. Vsaka med njimi ima svoje značilnosti, tako glede na njeno socialno, starostno in izobrazbeno strukturo kot glede na zgodovinski in političnogeografski kontekst, $v$ katerem jo opazujemo.

Če se ob koncu vrnem k izhodiščni lestvici občutenja etnične identitete, lahko na podlagi orisanih izkušenj in izhodišč predstavljeni gibljivi lestvici ob bok dodam še odločitev za poslovno sodelovanje $v$ okviru poslovnih združenj ali neposredno s slovenskimi partnerji v diaspori ali matični domovini. Značilnost te dejavnosti je, da je lahko navzoča pri katerikoli od naštetih »kategorij«. Za vstop v polje »etnične ekonomije« se lahko odloči tudi nekdo, ki sicer nima nikakršne druge povezave s Slovenijo ali slovensko izseljensko skupnostjo in morda komaj pozna svoje korenine; kot "poslovno sodelovanje« pa na neki način lahko razumemo tudi preselitev v Slovenijo in zaposlitev $\mathrm{v}$ njej.

Da bi posamezniki in poslovna združenja, ki jih zanima udejanjanje slovenskosti tudi v obliki dejanskega poslovnega sodelovanja s Slovenijo, lahko naredili bistveni korak naprej, bo treba predvsem v slovenski državni oziroma javni upravi še marsikaj urediti. Ne v smislu privilegiranosti ali diskriminacije drugih, pač pa s splošnim zmanjševanjem birokratizacije, klientelizma in še zlasti raznih fobij, ki tujcem - med katere $v$ tem primeru spadajo tudi, ali včasih še bolj, poslovneži slovenskega rodu onemogočajo vstop na naše tržišče. ${ }^{24}$

Do premikov pa kljub zgornji ugotovitvi vendarle prihaja. Celo v širši javnosti pojem »slovenski izseljenec dobiva drugačne konotacije kot v času stereotipa »polke in klobase« - sodobni slovenski izseljenec je vedno pogosteje razumljen kot študent, ki si nabira izkušnje v tujini, strokovnjak, pogumen podjetnik (!) itd. Še več, ob razmeroma hitrem »odmiranju« do nedavnega ustaljenih oblik »društvenega« življenja, ki so bile značilnost prve generacije izseljencev pretežno nižjega izobrazbenega in socialnega izvora, se ob hkratni uveljavitvi novih načinov komuniciranja (internet) vedno bolj uveljavlja nova podoba slovenskega izseljenstva. To pa v veliki meri temelji prav na »gospodarskem« sodelovanju z matično domovino ali vsaj na tovrstnem načinu razmišljanja.

24 O tovrstnih težavah so na konferenci Etnična ekonomija in Slovenci zunaj RS 4. 7. 2012 v LjubIjani razpravljali podjetniki slovenskega rodu iz Brazilije, Švice, Nemčije, Bolgarije, Italije, Avstrije, Kanade, BiH in Kitajske (dosegljivo v arhivu RTV Slovenija, Radio Slovenija, 1. program, oddaja Studio ob 17h). S to problematiko se dejavno sooča Društvo v tujini izobraženih Slovencev - VTIS, ki je decembra 2016 na Vlado RS naslovilo publikacijo s poudarjenimi devetimi glavnimi težavami pri sodelovanju z matično državo in vračanju na študij, delo ali v raziskovalno dejavnost (VTIS 2016). 


\section{VIRI IN LITERATURA}

Canadian Slovenian Chamber of Commerce (2010). 2010/2011 Business Directory. Toronto.

Canadian Slovenian Chamber of Commerce (2016). 2016 Summer Bulletin. Toronto: CSCC.

Durnik, Mitja (2017). Slovenian Immigrants and Ethnic Economy in Modern Canada. Dve domovini / Two Homelands 46, 103-118.

Durnik, Mitja, Gombač, Jure (2012). Theorizing the Potential of Political Economy and Social Economy Approaches in Studying the Structure of Ethnic Economies. Dve domovini / Two Homelands 35, 119-133.

Fong, Eric, Ooka, Emi (2002). The Social Consequences of Participating in the Ethnic Economy. International Migration Review 36/1, 125-146.

Gelt, Draga (ur.) (2011). From Dreams to Reality / Od sanj do resničnosti. Sydney: Slovenian Media House.

Klemenčič, Matjaž (1995). Slovenes of Cleveland: The Creation of a New Nation and a New World Community: Slovenia and the Slovenes of Cleveland. Novo mesto: Dolenjska založba.

Klemenčič, Matjaž (2006). A Survey of Research on Slovene Immigration to the U.S.A. Razprave in gradivo / Treaties and Documents 48-49, 80-98.

KSKJ Life (2015). Community Connection - A Guide to Your Membership - KSKJ Life Annual Report. Joliet.

Light, Ivan (2004). Immigration and Ethnic Economies in Giant Cities. International Social Science Journal 181, 385-398.

Light, Ivan (2010). The Ethnic Economy: Handbook of Economic Sociology. Princeton: Princeton University Press, 650-677.

Light, Ivan, Sabagh, Georges, Bozorgmehr, Mehdi, Der-Martirosian, Claudia (1993). Internal Ethnicity in the Ethnic Economy. Ethnic \& Racial Studies 16/4, 581-597.

Lukšič Hacin, Marina, Toplak, Kristina (2012). Teoretizacija multikulturalizma in etnične ekonomije v luči ohranjanja kulturne dediščine med migranti. Dve domovini / Two Homelands 35, 107-117.

Marcus, Alan P. (2011). Experiencing Ethnic Economies: Brazilian Immigrants and Returnees. Journal of Immigrant \& Refugee Studies 9, 57-81.

Mulec, Breda (2012). Kroženje možganov in (ne)povezanost z gospodarstvom. Referat na strokovno-znanstvenem posvetu Etnična ekonomija in Slovenci po svetu, 4. 7. 2012. Ljubljana: Inštitut za slovensko izseljenstvo ZRC SAZU.

Novak Lukanovič, Sonja (2012). Gospodarstvo in identiteta manjšine. Referat na strokovno-znanstvenem posvetu Etnična ekonomija in Slovenci po svetu, 4. 7. 2012. Ljubljana: Inštitut za slovensko izseljenstvo ZRC SAZU.

OECD (2012): Connecting with Emigrants - A Global Profile of Diasporas. Pariz: OECD Publishing, 208-209.

Pahor, Milan (1989). Slovensko denarništvo v Trstu. Trst: BCTKB. 
Pahor, Milan (1998). Lastno gospodarstvo jamstvo za obstoj. Trst: SDGZ-URES.

SPIRIT Slovenija (2017). Seznam prejemnikov sredstev iz Javnega razpisa za sofinanciranje izvajanja dejavnosti slovenskih poslovnih klubov v tujini v letu 2017, http://www. spiritslovenia.si/resources/files/seznamprejemnikovSPK2017.pdf (8. 8. 2017).

Toronto Backgrounder (2012), https://www1.toronto.ca/city_of_toronto/social_development_finance__administration/files/pdf/language_2011_backgrounder. pdf (25. 10. 2012).

Vah Jevšnik, Mojca; Lukšič Hacin, Marina (2011). Theorising Immigrant/Ethnic Entrepreneurship in the Context of Welfare States. Migracijske i etničke teme 27, 249-261.

VTIS (2016). Izzivi v tujini izobraženih Slovencev. Ljubljana: Društvo v tujini izobraženih Slovencev (VTIS), 26 str.

Žigon, Zvone (1998). Otroci dveh domovin. Ljubljana: Inštitut za slovensko izseljenstvo ZRC, Založba ZRC.

Žigon, Zvone (2001). Iz spomina v prihodnost. Ljubljana: Inštitut za slovensko izseljenstvo ZRC, Založba ZRC.

Žigon, Zvone (2003). Preservation of Ethnic Identity among Slovenian Immigrants in the Era of Globalization. Referat na: Social Change in the Age of Globalization, 36th World Congress, 7.-11. julij 2003. Peking: International Institute of Sociology.

Žigon, Zvone (2011). Diplomacija Slovenije med/z izseljenci: Primer mesta Cleveland (ZDA) (ur. Boštjan Udovič). Diplomacija med teorijo in prakso. Ljubljana: Fakulteta za družbene vede, 179-200.

Žigon, Zvone (2012). Poslovno sodelovanje kot nova (odrešilna?) oblika udejanjanja etnične identitete $v$ izseljenstvu. Referat na strokovno-znanstvenem posvetu Etnična ekonomija in Slovenci po svetu, 4. 7. 2012. Ljubljana: Inštitut za slovensko izseljenstvo ZRC SAZU. 


\section{SUMMARY}

\section{BETWEEN BUSINESS AND PATRIOTISM: THE ETHNIC ECONOMY AND SLOVENIANS OUTSIDE SLOVENIA Zvone ŽIGON}

The author first describes various forms of ethnic identity and ethnic economies, and then focuses on the Slovenian ethnic community living outside of Slovenia. Each of the forms has its own specifics, depending on social and educational structure and on historical and politico-geographic context.

In order to more easily perceive the multifacetedness of the personal and ethnic identities of emigrants, the author uses his own model of a moveable scale of forms and levels of identity among members of generations of descendants of Slovenian emigrants, to which we can add a decision to cooperate in business in the form of (ethnic) business associations or directly with Slovenian partners in diaspora or in Slovenia itself. The scale includes nine categories, ranging from mere awareness of one's ethnic origins to occasional or regular participation in organised immigrant or emigrant communities, visiting the homeland and the decision to move back to the country of one's parents. Even people who have no connection with Slovenia and with the organized Slovenian diaspora can participate in the ethnic economy.

The author finds that there are a lot of things that should be done in Slovenia at the level of the state and public administration to promote the increased implementation of the Slovenian ethnic economy model in order to assist individuals and associations which are interested in economic cooperation with Slovenia. This should be accomplished primarily through reducing bureaucracy, clientelism and especially various phobias which prevent foreigners - including ethnic Slovenes - from entering the Slovenian market.

However, certain changes are occurring. The term "Slovenian emigrant" has been gaining different connotations recently than it had during the days of the "polka and sausage" stereotype, even among the general public. A modern Slovenian emigrant is increasingly understood as a student gaining experience abroad, a professional or a daring entrepreneur.

Due to the relatively fast disappearance of established models of participation in societies and associations, as was characteristic of first-generation Slovenian emigrants, who were predominantly from lower educational and social strata, a new model of Slovenian emigration is appearing in parallel with new forms of communication (internet), which is to a great extent based precisely on economic cooperation with the motherland, or at least on this way of thinking. 